the method, and in the domestic journals, when a method is specified, I have found the Esbach method used as a sine qua non of a urinary examination. I do not believe physicians wittingly subscribe to an error.

I have consulted Neubauer and Vogel's "Analyse des Harns" repeatedly and very thoroughly. As our method requires rarely more than 0.5 c.c. of urine, corresponding to 0.2 pro mille albumin, and in cases of pronounced albuminuria usually much less $(0.05$ c.c. urine corresponding to 2 . pro mille albumin) it must be apparent that the amount of albumose, peptones, xantlin bases, uric acid, kreatinin and other substances precipitated by our solution, contained in 0.05 c.c. urine, must be very small. I do not know how sensitive to these substances Tsuchiya's solution of phosphotungstic acid is, and should be pleased to be enlightened on this point.

"Almost all normal urine will give a preciptate after a short while" is a statement which may or may not be true, and $I$ should like further information as to just how long a "short while" is, I would inform my critic, however, that I have met with no "normal" urine that gives a precipitate in the few (10 to 30$)$ seconds it takes me to make my test.

\section{Nutmeg Poisoning.}

Pukrkohe, New Zealasd, Oct. 26, 1908.

To the Editor:-The other day I had a patient who took at one dose, on an empty stomach, a freshly ground nutmeg, followed by a heavy meal. When I reached her five hours after the administration of the nutmeg, the woman was in a state of collapse. The pulse was 50 and very feeble. The respirations were between 30 and 40 and every second or third breath was a sigh. The skin and extremities were cold and the face flushed and mottled. The temperature was 95 .

I gave $1 / 30$ of a grain of strychnin sulphate hypodermically every three hours and $7 \frac{1}{2}$ grains ammonium carbonate with 20 minims each of spirits of ether and spirits of chloroform every four hours. I placed hot bottles all around the body and gave a cup of hot milk every half hour. The patient's pulse and temperature returned to normal in twenty-four hours. She then seemed fully recovered, has since improved, and now is as before the dose.

She took the nutmeg to check profuse and irregular menstruation. Once previously she had taken a much smallar dose for the same purpose with the desired result, and now having a worse attack, she took a larger dose, reasoning, no doubt, that if a little was good, much was hetter.

I can find nothing satisfactory about nutmeg poisoning in my books and wonder if there is any record of a similar ease. JoHN S. ReEkie, M.D., Ch.M.

\section{Overrated Prospects for Physicians in Nevada}

\section{FalloN, Nev., Dec. 18, 1908.}

To the Editor:-The literature sent out by the Reclamation Service on the Tucker-Carson Irrigation Project has induced nine physicians to come here and locate among a population of but few over 2,000, and not growing any.

Almost weekly, some eastern physician comes out at considerable expense and finds that here there are at least seven physicians more than the place needs. It is much the same all over Nevala, and this communication is written in the hope that it will save money for a class of professional men who have little to throw away.

\section{JOHN E. WORDEN.}

\section{Correction in Hemolysis Article}

Cleveland, Oirro, Dec. 21, 1908.

To the Editor:-I desire to correct an error in my article on hemolysis, published in The Jockxal, Dec. 12, 1908, under t!. subdivision, "Setting Up the Test." The serum for the control test should be heated at 55 degrees C. for ten minutes before the corpuscles are added. The tubes should then be placed in the refrigerator with the heated tubes until all are of the same temperature. Should the corpuscles be heated, as wrongly stated in my previous desiption, they would be hemolyzed by the heat alone.

\section{Queries and Minor Notes}

Axonyous Communcatrons will not be noticed. Queries for this column-must be accompanied by the writer's name and address. but the request of the
will be faithfully observed.

\section{HYORARGYRUM SUCCINIMIDUM IN TUBERCULOSIS}

Ias Animas, Colo., Dec. 14, 1908

To the Elitor:- Permit me to reply to the letter by Dr. Henriksen, in 'THE JotRNAL, Dec. 12,1908 , on the above-named subject. Had Dr. Ifenriksen carefully read my article in the $U$. S. Natal Bulletin for April, 1908, he would have seen that I consider any salt of mercury which can be administered by intramuscular injection a strong antituberculous agent. and that I use the succinimid of melcury because from long experience and observation than other salts of mercury in the treatment of both tuberculosis and syphilis by hypodermic injection. Mercury given by mouth or by inunction is of little, if any, value in the treatment of tuiser-
culous infection.
B. L. WRIGHT, II.D.

Cleveland, Ohio, Dec. 11, 1908.

To the Eatitor:-In The Journal December 12, is a letter by $H$. K. Henriksen criticizing the recommendation of the use of hydrargyrum stccinimidum, on the ground that it is a very rare salt, difficult to obtain, and little known. It seems to me that Dr. Henriksen is a little hasty in his conclusions. In 1903 , when 1 was at Ehrmann's clinic, he recommended this salt as by far the 1 was at Ehrmann's clinic, he recommended this salt as by far the best soluble form of mercury, on account of its easy solubility, the large dosage possible, its painlessness and its freedom from liability to cause abscesses. I have used it myself for nearly five years and so have many others who are familar with the treatment of syphilis. It can readily be obtained and its price is such as to preclude any undue advantage being taken by the manufacturer's.
W. E. SAMPLIXEK, M.D.

\section{DEATHS OF PHYSICIANS FROM ACCIDENTS AND SLRGICAL} OPERATIONS

To the Editor:-Perusal of the death list of THE Jotrial indicates to me that more than 10 per cent. of all deaths amcnir physicians result from accidents and surgical operations. Why is it? It would seem that such men should be nearly free from such conditions. L. K. ABBo'T, M.D., Monterey, Calif.

Axswer. - We agree that deaths of physicians from accidents and surgical operations seem frequent. Reduced to actual percentages, however, they are not so frequent as our correspondent suggests. Each year we give a summary of the deaths of physicians for the previous year. The summary for 1908 appears in the edito:ial department of this issue, page 52 .

For the last three year's violence, which includes homicide and suicide, has caused very nearly 7 per cent. of the deaths among physicians; namely, 6.75 per cent. in $1905,6.98$ per cent. in 1906,7 per cent. in 1907 and 7.6 per cent. in 1908 . Operations were assigned as the cause of death in 2.59 per cent. in 1905 , in 0.03 per cent, in 1906 , and in 0.66 per cent. in 1908 .

The physician's calling is attended with considerable dangel : he travels a great deal; he deals with violent persons, including criminals, the insane, and those who are delirious from disease. Health officers necessarily incur the enmity of the ignorant, who object to sanitary restrictions. In this connection is of interest the report of an address by Mr. Kipling and some comments thereon, which were quoted in The Joursal, Nov, 14, 1908, page 1719 .

\section{LAWS AND LITERATURE ON TUBERCULOSIS}

To the Editor:-Please refer me to the literature dealing with the legislation in various states against the spread of tuberculosis. Watson S. RaNkin, M.D., Wake Forest, N. C:

To the Eator:-Can you tell me where $I$ can secure cards and pamphlets for distribution to tuberculosis patients giving hints as to proper care in the home?

$$
\text { ARTHCr Bowles, M.D., Fleva, Wis. }
$$

A.vswer.-Each of the above correspondents will find an answer to his question in "The Campaign Against Tuberculosis in the Cnited States." This valuable and interesting book, reviewed Nov. 21, 1908, p. 1798, can be obtained for one dollar from the Charities Publication Society, 125 E. $22 \mathrm{~d}$ St., New York City. The price is merely a nominal one since the expense is in part met by an endowment fund. The book contains a summary of the laws of each state and enumerates and describes all the antituberculosis sanitariums and societies of the United States. From some of the latter, one may secure advice and samples of antituberculosis literature, including cards and pamphlets.

\section{HYPOWERMIC INJECTIONS OF CALOMEL IN SYPHIIIS}

To the Editor:-Please give the details of the $12,1908$. syphilis by injection of calomel. $\mathrm{L}$. $\mathrm{L}$.

Axswer.-The calomel should be suspended in water by means of mucilage of acacia, in oil, or in petrolatum or glycerin. The cose for a single injection should be from one to three grains, 